\title{
Development and Application of Intelligent Environmental Protection Testing Sealer
}

\author{
Weian Wang ${ }^{1,2}$ \\ ${ }^{1}$ The Third Oil Production Plant, Daqing Oil Field Co.Ltd. 163113,China; \\ ${ }^{2}$ Geological brigade management room 163113,China
}

Keywords: law of environmental protection; plug leakage; test sealer; closed test; measurement efficiency

\begin{abstract}
Intelligent environmental protection testing sealer is a new type of cable sealer. It is designed for the serious leakage of original testing sealer of injection wells, difficulty to operate of the down-hole equipment and other issues. Air-core motor resistance self-styled technology, sealed packing anti-partial wear technology, auxiliary salvaging technology and intelligent controlling motor technology are used to not only solve the original types of injection wells test sealer's serious leakage, but also the operating difficulty of high efficiency measurement equipment. The problem that free climbing lubricator technology can't adjust the plug manually and be applied to a large area is solved as well. Field application so far, the instrument successfully carried outrunning-pulling operation, the closed test and intelligent controlling. After 10 minutes of power, the main body temperature of the sealer can reach about $30^{\circ} \mathrm{C}$. In the winter test, the freezing situation of the test plug will not appear and the test team's measurement efficiency is improving. The device extends the service life of the cable and enables significant economic benefits.
\end{abstract}

\section{Introduction}

The testing sealer is mainly composed of four parts, as illustrated in Figure 1: First, the spray prevention part, consisting of the main sealed shell, two pressure relief baffle, three pressure relief ring, self-sealing column and shell pressure relief valve.Second, anti-partial wear part, consisting of the gland, two support ring and a self-sealing top column. And all of these are equipped with precious metal linear bearings Third, the resistance part, consisting of the self-sealing column, electromagnetic motor, control module, wireless transceiver module, external power supply composition. Last, auxiliary salvage part. See Fig.1.

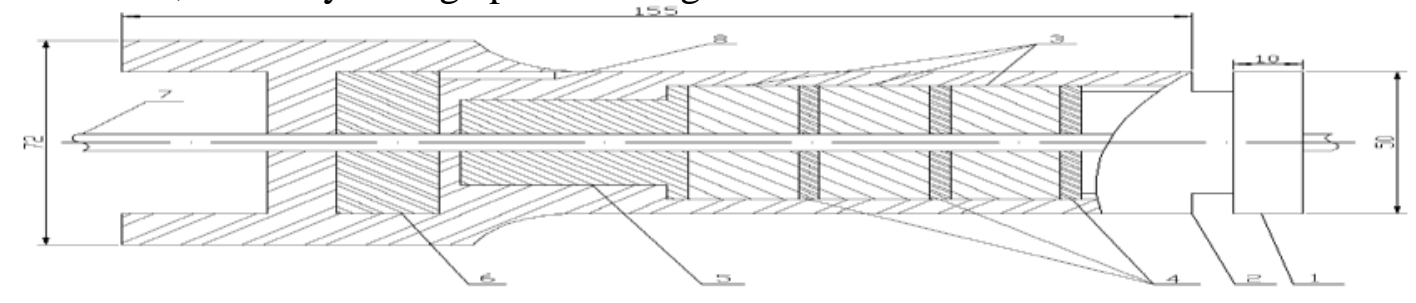

Fig.1 Schematic diagram of the intelligent environmental protection testing sealer

Illustrated description:1, screw gland 2, shell 3, seal gasket 4, block ring 5, self-sealing top column 6 , motor 7 , test cable 8 , motor terminal

\section{Performance and Characteristics of Intelligent Environmental protection Testing Sealers}

The testing sealer is a versatile blowout testing air core motor cable sealer with the following features:

(1) The gasket, motor, thread gland are middle hollow structure and testing wire or cable can pass them. The sealer is suitable for not only steel wire, but also cable, with a high compatibility.

(2) Compared with the one-piece gasket structure, the sealing of the three-gasket structure is more uniform. The design of the conical mating structure makes the gasket easier to gather inwardly, 
thus improving the sealing effect of the device, improving the pressure capacity of the sealer and realizing the closed test.

(3) The sealer is designed with tubing threads. When used, it can be directly connected to the nozzle through the tubing thread, no need to transfer with the connector.

(4) Using the motor as a power source, electronic control of the setting and unsetting process achieve. Control personnel effectively control motor to start and stop through the wired or wireless switch on the ground. Whenever the wire or cable does not go well, the motor can be stopped by the switch. So that the packing re-seal, the inner diameter of the wire channel in the testing sealer increase and the wire or cable can be successfully ran. And then the packing is settee through the switch to control motor to achieve closed test. This avoids the security risks brought by climbing high-level platform and improve the work efficiency.

(5) 10 minutes after the power, the main body temperature of the sealer can reach about $30^{\circ} \mathrm{C}$.So the case of frozen plug will not appear in winter test and the measurement efficiency is improved greatly.

\section{Analysis of Field Application Effect}

The new type of sealer was put into field test in March 2015 and has applied 10 sets of equipment to test 236 wells which included 76 wells to verify the anti-spray seal and anti-seal seal and 160 wells to verify the anti-wear and sealing life. Field application so far, the new environmental protection testing sealers all is ran and pulled smoothly. Closed test achieve in the armor cable testing process and the pressure rise only $0.2-0.3 \mathrm{MPa} .10$ minutes after the power, the temperature of sealers' main body reached about $30^{\circ} \mathrm{C}$. The case of frozen plug never appear. In addition, the use of the sealers can eliminate the impact from replacing the packing or tightening plug due to the large amount of plug leakage in the past on testing efficiency. And each team can test 1.5 times more per month. The relief valve leakage slightly when the instruments are ran and pulled, but the loss is less than $1 \mathrm{~m}^{3} / \mathrm{d}$. Sealing packing is used in more than 30 wells to be replaced and the operating life of armored cable is extended from the average of 6 months to 24 months or more. Around 22 accident wells caused by armored cable drop or card are reduced per year. Specific tests are as follows.

Anti - spray sealing technology to reduce sealer leakage. The testing sealer is mainly consist of the two-step decompression retainer and the same three wear-resistant packing components and self-sealing top column. In the test, the self-sealing column uses the fluid pressure in the wellhead to push the packing to achieve decompression seal from top to bottom and step by step. The average single well overflow of the 76 wells that used the sealer was only $0.93 \mathrm{~m}^{3} / \mathrm{d}$, which was lower than that of the conventional sealer by $0.67 \mathrm{~m}^{3} / \mathrm{d}$. This is environmentally friendly and can be recycled in plastic drums. (As shown in table 1).

Anti-wear sealing technology to extend the service life of seals. We know that the armored cable has a helical linear motion when it pass the inside of the testing sealer during the running and pulling of the instrument. In order to verify the wear and tear of the packing and cable, verify the reliability of the retainer and the linear bearing., the four sealers were tested for winter and summer wearing test In 2015 (see Table 2 for the testing data). Tests show that each sealer can test an average of 48 wells per summer, and each tank can be used to test an average of 32 wells per winter. While the original sealer only test 8 wells sealing packing before must being replaced. Thus, the new sealing packing's operation life is much longer than the original sealer. 
Table 1 Comparison of Leakage of New Sealers

\begin{tabular}{|c|c|c|c|c|c|}
\hline \multirow{2}{*}{$\begin{array}{l}\text { injection } \\
\text { flow rate }\end{array}$} & \multicolumn{3}{|c|}{ Wellhead pressure } & \multicolumn{2}{|c|}{$\begin{array}{l}\text { Average leakage of } \\
\text { single well }\left(\mathrm{m}^{3} / \mathrm{d}\right)\end{array}$} \\
\hline & $\leq 8.0 \mathrm{MPa}$ & $\begin{array}{l}\text { 8.1MPa } \\
11.9 \mathrm{MPa}\end{array}$ & $\geq 12.0 \mathrm{MPa}$ & $\begin{array}{l}\text { Original } \\
\text { sealer }\end{array}$ & $\begin{array}{l}\text { New } \\
\text { sealer }\end{array}$ \\
\hline$\leq 80 \mathrm{~m}^{3}$ & 10 & 6 & 2 & 1.6 & 0.7 \\
\hline $\begin{array}{l}81 \mathrm{~m}^{3} \sim \\
119 \mathrm{~m}^{3} \\
\end{array}$ & 7 & 10 & 11 & 3.6 & 0.9 \\
\hline$\geq 120 \mathrm{~m}^{3}$ & 3 & 12 & 15 & 5.0 & 1.1 \\
\hline total & 20 & 28 & 28 & & \\
\hline average & & & & 3.6 & 0.93 \\
\hline
\end{tabular}

Table 2 Comparison of anti-wear tests for new sealers

\begin{tabular}{|c|c|c|c|c|c|c|}
\hline \multirow[t]{2}{*}{ classification } & \multirow{2}{*}{$\begin{array}{l}\text { Number } \\
\text { of sealers }\end{array}$} & \multirow{2}{*}{$\begin{array}{l}\text { Number } \\
\text { of wells }\end{array}$} & \multicolumn{2}{|c|}{$\begin{array}{l}\text { Aperture changes } \\
\text { caused by retainer } \\
\text { wearing }(\mathrm{mm})\end{array}$} & \multirow{2}{*}{$\begin{array}{l}\text { Degree of Packing } \\
\text { wearing }\end{array}$} & \multirow[t]{2}{*}{ Loss of overflow } \\
\hline & & & $\begin{array}{l}\text { befor } \\
\text { e }\end{array}$ & after & & \\
\hline Summer & 2 & 96 & $\begin{array}{l}2.50 \\
\mathrm{~mm}\end{array}$ & $\begin{array}{l}2.65 \\
\mathrm{~mm}\end{array}$ & serious & $\begin{array}{l}\text { Loss is greater than } \\
2 \mathrm{~m}^{3} / \mathrm{d}\end{array}$ \\
\hline winter & 2 & 64 & $\begin{array}{l}2.50 \\
\mathrm{~mm}\end{array}$ & $\begin{array}{l}2.71 \\
\mathrm{~mm}\end{array}$ & serious & $\begin{array}{c}\text { Loss is greater than } \\
2 \mathrm{~m} 3 / \mathrm{d}\end{array}$ \\
\hline
\end{tabular}

Resistive sealing technology to shorten the running time of the instrument, improve the success rate of running down. Whether the test equipment can be decentralized quickly is the main indicator to check whether the testing sealer is developed successfully. And the most critical parts is the distance from the wellhead to 200 meters depth. When the test equipment is decentralized, the frictional resistance of the sealing packing increase due to the self-sealing pressure inside the testing sealing plug, resulting in difficulties in the testing instrument entry. Sometimes it is needed to manually run the wire by more than $200 \mathrm{~m}$, bringing great difficulty to the field test. The success rate of the original sealer was only $71.4 \%$. As can be seen from the table below, the success rate of the new testing sealer being sent on one trip to $96.3 \%$ and the success rate is greatly improved.

Through the 76 wells track testing records, we found that the time used by the instrument to be sent to $200 \mathrm{~m}$ from wellhead and the success rate of the instrument being sent on one trip have an important relationship with wellhead water injection pressure. The higher the water injection pressure, the harder to run, the longer the time, the lower the success rate. The amount of overflow caused by the instrument is also related to the injection pressure, and the amount of overflow caused by the increase of the water injection pressure also increases (see Table 3).

Table 3 Comparison of the average time of the new sealer to be sent to $200 \mathrm{~m}$ depth

\begin{tabular}{|c|c|c|c|c|c|c|c|}
\hline \multirow{2}{*}{ Wellhead pressure } & \multirow{2}{*}{$\begin{array}{l}\text { Number } \\
\text { of wells }\end{array}$} & \multirow{2}{*}{$\begin{array}{l}\text { time of the new } \\
\text { sealer to be sent to } \\
200 \text { m depth(min) }\end{array}$} & \multicolumn{2}{|c|}{$\begin{array}{l}\text { Once down to } \\
\text { succeed }\end{array}$} & \multicolumn{2}{|c|}{$\begin{array}{l}\text { twice down to } \\
\text { succeed }\end{array}$} & \multirow{2}{*}{$\begin{array}{l}\text { Amount } \\
\text { of } \\
\text { Overflow } \\
\left(\mathrm{m}^{3} / \mathrm{d}\right)\end{array}$} \\
\hline & & & $\begin{array}{l}\text { we } \\
\text { ll }\end{array}$ & $\begin{array}{l}\text { Success } \\
\text { rate }(\%)\end{array}$ & $\begin{array}{l}\text { we } \\
\text { ll }\end{array}$ & $\begin{array}{r}\text { Succes } \\
\text { s rate }(\%)\end{array}$ & \\
\hline$\leq 8.0 \mathrm{MPa}$ & 20 & 5.0 & 20 & 100.0 & & & 0.7 \\
\hline $8.1 \mathrm{MPa} \sim 11.9 \mathrm{MPa}$ & 28 & 5.8 & 27 & 96.4 & 1 & 100.0 & 0.8 \\
\hline$\geq 12.0 \mathrm{MPa}$ & 28 & 7.6 & 26 & 92.9 & 2 & 100.0 & 1.2 \\
\hline Total & 76 & & 73 & 96.1 & 3 & 100.0 & \\
\hline Average & & 6.2 & & 96.3 & & 100.0 & 0.93 \\
\hline
\end{tabular}




\section{Conclusion}

(1) Intelligent environmental testing sealers adopt three-gasket structure and the design of conical mating structure makes the gasket easier to gather inwardly. These features improve the sealing effect of the device, realize the closed test, improve the quality of the test data, and lay the foundation for improving the oilfield development effect.

(2) The intelligent environmental protection sealer uses the motor as the power source to achieve the electronic control of setting and unsetting process , to ensure the wire or cable running smoothly, avoid the security risks of climbing high-platform to tighten testing plug , improve work efficiency.

\section{Reference}

[1]. Xu Jianjun, $\mathrm{Xu}$ Yan-chao, Yan, Li-me,et.al. Research on the method of optimal PMUplacement.International Journal of Online Engineering,v9, S7, p24-29, 2013

[2]. Xu Jian-Jun,Y. Y. Zi.,Numerical Modeling for Enhancement of OilRecovery via Direct Current. International Journal of Applied Mathematics andStatistics,2013,43 (13） : 318-326

[3]. Longchao, ZhuJianjun, Xu; Limei, Yan.Research on congestion elimination method of circuit overload and transmission congestion in the internet of things. Multimedia Tools and Applications, p 1-20, June 27, 2016

[4]. Yan Limei, Zhu Yusong, Xu Jianjun,et.al.Transmission Lines Modeling Method Based on Fractional Order Calculus Theory. TRANSACTIONS OF CHINA ELECTROTECHNICAL SOCIETY, 2014 ,Vol.29,No. 9:260-268 (In Chinese)

[5]. YAN Li-mei, CUI Jia, XU Jian-jun,et.al.Power system state estimation of quadrature Kalman filterbased on PMU/SCADA measurements. Electric Machines and Control. 2014, Vol.18 No.6,: 78-84. (In Chinese)

[6].YAN Limei,XIEYibing, XU Jianjun, et.al. Improved Forward and Backward Substitution in Calculation of Power Distribution Network with Distributed Generation. JOURNAL OF XI'AN JIAOTONG UNIVERSITY,2013, Vol.47, No.6,p117-123. (In Chinese)

[7]. Xu J.J., Gai D., Yan L.M. A NEW FAULT IDENTIFICATION AND DIAGNOSIS ONPUMP VALVES OF MEDICAL RECIPROCATING PUMPS. Basic \& Clinical Pharmacology \& Toxicology, 2016,118 (Suppl. 1), 38-38

[8]. Xu Jianjun, Wang Bao'e, Yan Limei, Li Zhanping. The Strategy of the Smart Home Energy Optimization Control of the Hybrid Energy Coordinated Control. Transactions of China Electrotechnical Society, 2017, 32(12) 214-223. 